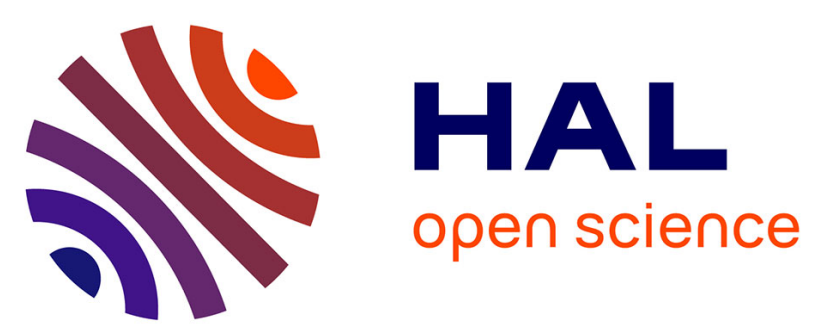

\title{
Influence of nontrophic interactions between benthic invertebrates on river sediment processes: a microcosm study
}

Florian Mermillod-Blondin, Magali Gérino, Sabine Sauvage, Michel Creuzé Des Châtelliers

\section{To cite this version:}

Florian Mermillod-Blondin, Magali Gérino, Sabine Sauvage, Michel Creuzé Des Châtelliers. Influence of nontrophic interactions between benthic invertebrates on river sediment processes: a microcosm study. Canadian Journal of Fisheries and Aquatic Sciences, 2004, vol. 61, pp. 1817-1831. 10.1139/F04-114. hal-00780256

\section{HAL Id: hal-00780256 https://hal.science/hal-00780256}

Submitted on 23 Jan 2013

HAL is a multi-disciplinary open access archive for the deposit and dissemination of scientific research documents, whether they are published or not. The documents may come from teaching and research institutions in France or abroad, or from public or private research centers.
L'archive ouverte pluridisciplinaire HAL, est destinée au dépôt et à la diffusion de documents scientifiques de niveau recherche, publiés ou non, émanant des établissements d'enseignement et de recherche français ou étrangers, des laboratoires publics ou privés. 


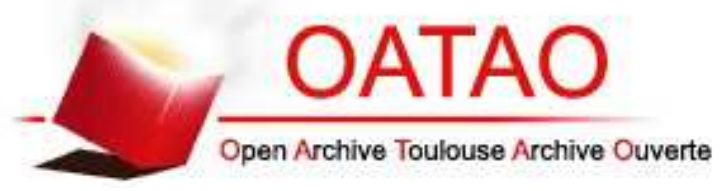

\section{Open Archive Toulouse Archive Ouverte (OATAO)}

OATAO is an open access repository that collects the work of Toulouse researchers and makes it freely available over the web where possible.

This is an author-deposited version published in: http://oatao.univ-toulouse.fr/ Eprints ID: 5865

To link to this article: DOI: $10.1139 / \mathrm{F} 04-114$

URL: http://dx.doi.org/10.1139/F04-114

To cite this version: Mermillod-Blondin, Florian and Gérino, Magali and Sauvage, Sabine and Creuzé des Châtelliers, Michel Influence of nontrophic interactions between benthic invertebrates on river sediment processes: a microcosm study. (2004) Canadian Journal of Fisheries and Aquatic Sciences (CJFAS), vol. 61 ( $\left.{ }^{\circ} 10\right)$. pp. 1817-1831. ISSN 12057533

Any correspondence concerning this service should be sent to the repository administrator: staff-oatao@ listes.diff.inp-toulouse.fr 


\title{
Influence of nontrophic interactions between benthic invertebrates on river sediment processes: a microcosm study
}

\author{
Florian Mermillod-Blondin, Magali Gérino, Sabine Sauvage, and Michel Creuzé \\ des Châtelliers
}

\begin{abstract}
The main objective of this study was to measure the impact of benthic invertebrate diversity on river sediment processes. We quantified the effects of interactions between three taxa (asellids, chironomid larvae, and tubificid worms). The impacts of different taxa richness treatments were measured on sediment reworking, $\mathrm{O}_{2}$ concentrations, bacterial abundances, and numbers of active bacteria in slow filtration sand-gravel columns. The coefficients of sediment reworking measured in multitaxa treatments were lower than those predicted from one-taxon treatments. The interactions among invertebrates also significantly reduced $\mathrm{O}_{2}$ concentrations in sediments. These results were probably due to interactions between the different sediment structures produced by each taxon (tubes, macropores, and fecal pellets) that modified water flow and associated microbial activities in the interstitial habitat. The stimulation of aerobic microbial processes with two- and three-taxa treatments, whereas one-taxon treatments could increase or decrease $\mathrm{O}_{2}$ consumption in columns, indicates that interactions among invertebrates limited the variability of the system functioning. We suggest that, beyond a small number of detritivorous taxa, a threshold effect on bioturbation process and microbial activities was produced by animals in the experimental system. Finally, the interactions between taxa played a significant role in microbial processes in the system studied.
\end{abstract}

Résumé : Le but de cette étude était de mesurer l'impact de la diversité des invertébrés sur le fonctionnement d'un milieu sédimentaire de rivière. Nous avons quantifié les effets des interactions entre trois taxons (aselles, larves de chironomes et oligochètes tubificidés). Les effets produits par différents traitements en invertébrés ont été mesurés sur le remaniement sédimentaire, les concentrations en $\mathrm{O}_{2}$, les abondances totales en bactéries et le nombre de bactéries actives dans des colonnes filtrantes remplies de sables et graviers. Les coefficients de remaniement sédimentaire mesurés dans les traitements avec plusieurs taxons étaient plus faibles que ceux estimés à partir des effets individuels produits par chaque taxon. Les interactions entre les taxons ont aussi produit une diminution significative des concentrations en $\mathrm{O}_{2}$ dans les sédiments. Ces résultats étaient probablement liés à des interactions entre les structures sédimentaires produites par chaque taxon (tubes, macropores et pelotes fécales), lesquelles modifient les flux d'eau et les activités microbiennes dans l'habitat interstitiel. La stimulation des processus microbiens aérobies dans les traitements avec deux et trois taxons alors que les traitements avec un seul taxon peuvent stimuler mais aussi réduire la consommation en $\mathrm{O}_{2}$ dans les colonnes indique que les interactions entre invertébrés limitent la variabilité dans le fonctionnement du système. Nous supposons que, au delà d'un nombre faible de taxons, un effet seuil est observé sur le processus de bioturbation et les activités microbiennes dans le système expérimental. En définitive, les interactions entre les taxons jouent un rôle significatif sur les processus microbiens dans le système étudié.

\section{Introduction}

In the last 10 years, an increasing number of studies have focussed on the effect of species diversity on ecosystem properties (Naeem et al. 1994; Loreau et al. 2002; Jonsson and Malmqvist 2003). The impact of biodiversity on ecosystem processes depends on the functional characteristics of each species but also on the interactions among species present in the community (Wardle et al. 1997; van der Heijden et al. 1998; Loreau et al. 2001).

F. Mermillod-Blondin ${ }^{1}$ and M. Creuzé des Châtelliers. UMR-CNRS 5023, Laboratoire d'Écologie des Hydrosystèmes Fluviaux, French National Centre for Scientific Research and University Claude Bernard Lyon I, Domaine Scientifique de la Doua, 69622 Villeurbanne cedex, France.

M. Gérino and S. Sauvage. FRE CNRS-UPS 2630, Laboratoire d'Écologie des Hydrosystèmes, French National Centre for Scientific Research and University Paul Sabatier, 29 rue Jeanne Marvig, 31055 Toulouse, France.

${ }^{1}$ Corresponding author (e-mail: mermillo@univ-lyon1.fr). 
At the water-sediment interface in marine and lake systems, the effects of various benthic invertebrates on the bioturbation process and their influences on biogeochemical cycling have been widely studied (Fukuhara and Sakamoto 1987; Hansen and Kristensen 1998; Stief and de Beer 2002). However, the impacts of assemblages of benthic invertebrates on nutrient fluxes have been analysed only very recently in marine sediments (Emmerson and Raffaelli 2000; Emmerson et al. 2001; Raffaelli et al. 2003). These studies demonstrated that the diversity of functional traits (e.g., mode of bioturbation) strongly affects the ecosystem processes.

In rivers, the exchange between the surface and the riverbed sediments (hyporheic zone) plays a key role in organic matter processing and nutrient cycling (Grimm and Fisher 1984; Boulton et al. 1998; Morrice et al. 2000). Battin et al. (2003) showed that hyporheic respiration accounts for $41 \%$ of whole-ecosystem respiration in White Clay Creek (Pennsylvania). Triska et al. (1993) demonstrated that the nitrogen cycle in rivers was dependent on microbial processes occurring in bed sediments. Marmonier et al. (1995) also reported high efficiency of interstitial habitats in organic matter processing. Despite such functional importance of these sedimentary systems in organic matter processing and nutrient cycling in the hydrosystems, the impact of invertebrate diversity on biogeochemical processes occurring in river sediments (characterized by coarse particles and an advective flux of water) has been poorly studied (Danielopol 1989; Boulton 2000).

It has, however, been demonstrated that benthic invertebrates may significantly affect physical, chemical, and microbial processes occurring in such river sediment habitats (Danielopol 1989; Torreiter et al. 1994; Mermillod-Blondin et al. 2000a, 2003). In a previous study (Mermillod-Blondin et al. 2002), three invertebrate taxa typically associated with river sediment systems (asellids, chironomids, and tubificid worms) were described as three distinct ecosystem engineers (sensu Jones et al. 1994). Their activities in sediments were tested separately. They corresponded to three specific modes of bioturbation, producing different effects on sediment structure and microbial activities.

The aim of the present study was to test the influence of interactions among taxa (assemblages of the three taxa) on sediment properties and processes (sediment reworking, $\mathrm{O}_{2}$ concentrations, and microbial characteristics). We used experimental microcosms with several treatments of different taxa richness combinations and measured the resulting processes. We predicted that the three benthic taxa would strongly interact in sediments by modifying the same physical habitat in different ways. Therefore, system functioning tested with a mixture of taxa was predicted to be different from that calculated by the summation of the individual roles of each taxon forming the mixture. To measure the impact of interactions between taxa, we used sediment reworking as an indication of the effect of taxa assemblages on the physical structure of sediments and dissolved $\mathrm{O}_{2}$ concentration as an indicator of respiration in river sediments (with a constant flow rate, dissolved $\mathrm{O}_{2}$ in pore water is determined by the distance from the $\mathrm{O}_{2}$ source and the rate of $\mathrm{O}_{2}$ consumption by microorganisms, Malard and Hervant 1999). The abundances of bacteria and electron transport system (ETS) ac- tive bacteria were measured to estimate the impact of invertebrates on biofilm characteristics.

\section{Materials and methods}

\section{Experimental design}

Experiments took place in gravel-sand filtration columns (50 cm high, $10 \mathrm{~cm}$ in diameter) (Fig. 1) modified from Torreiter et al. (1994) and Griebler (1996). Each column was filled with sand $(60-630 \mu \mathrm{m})$ previously incubated during 4 days with bacteria and cellulose powder $(0.5 \%$ of sediment mass) as source of particulate organic matter at a final concentration equivalent to that measured in secondary channels of the Rhône River (Mermillod-Blondin et al. 2000b) and with calcinated $\left(550{ }^{\circ} \mathrm{C}\right)$ fine gravel $(4-5 \mathrm{~mm})$ to a height of $40 \mathrm{~cm}$. Constant masses of gravel $(590 \mathrm{~g})$ and incubated sand $(210 \mathrm{~g})$ were alternately added to obtain a heterogeneous interface with presence of zones where sand was trapped and zones with macropores. A water column $(6-10 \mathrm{~cm})$ was maintained at the surface of the sediment to simulate the overlying river water. Openings in the column at different depths permitted the collection of water and fine sediments with a syringe. Further details of the columns are given in Mermillod-Blondin et al. (2000a).

The experiments were performed in a constant-temperature room at $15 \pm 0.5{ }^{\circ} \mathrm{C}$ with a $12 \mathrm{~h}$ light : $12 \mathrm{~h}$ dark cycle. The sediment of the column was kept in the dark for suppressing photoautotrophic growth. Dechlorinated drinking water, permanently aerated to maintain high $\mathrm{O}_{2}$ concentrations, was continuously fed into the columns with a peristaltic pump. Before entering into the columns, the water was enriched with nitrate (to a nitrate concentration of $20 \mathrm{mg} \cdot \mathrm{L}^{-1}$ ) and dissolved organic carbon ( $2 \mathrm{mg}$ potassium acetate $\cdot \mathrm{L}^{-1}$ ) with another peristaltic pump to support biofilm activity (Fig. 1). These concentrations of carbon and nitrate were equivalent to those measured in secondary channels of the Rhône River (Mermillod-Blondin et al. 2000b). The resulting infiltration rate was $2.0 \pm 0.1 \mathrm{~mL} \cdot \mathrm{min}^{-1}\left(\right.$ Darcy velocity $\left.1.53 \mathrm{~cm} \cdot \mathrm{h}^{-1}\right)$, which generated an interstitial water velocity of $3.75 \mathrm{~cm} \cdot \mathrm{h}^{-1}$. This velocity corresponded to values measured in the hyporheic zone of streams (Triska et al. 1993; Morrice et al. 2000). The first measurements were made 3 days after the beginning of the water flow after the hydraulic properties had stabilized.

As in previous studies (Mermillod-Blondin et al. 2000a, 2002), one experimental set consisted of four columns: three columns (animal columns) with the same combination of taxa and one column (without animals) acting as a control. In the present study, we used seven experimental sets, giving eight treatments: (1) control without animals (seven columns), (2) 25 asellids (Asellus aquaticus, A treatment, three columns), (3) 50 chironomids (Prodiamesa sp., C treatment, three columns), (4) 100 tubificid worms (50 Limnodrilus spp. and 50 Tubifex sp., T treatment, three columns), (5) 25 asellids and 50 chironomids $(\mathrm{A}+\mathrm{C}$ treatment, three columns), (6) 25 asellids and 100 tubificid worms (A+T treatment, three columns), (7) 50 chironomids and 100 tubificid worms (C+T treatment, three columns), and (8) 25 asellids, 50 chironomids, and 100 tubificid worms $(\mathrm{A}+\mathrm{C}+\mathrm{T}$ treatment, three columns). The tested densities were equivalent to 3250 , 
Fig. 1. Schematic diagram of an experimental unit. DOC, dissolved organic carbon, ETS, electron transport system.

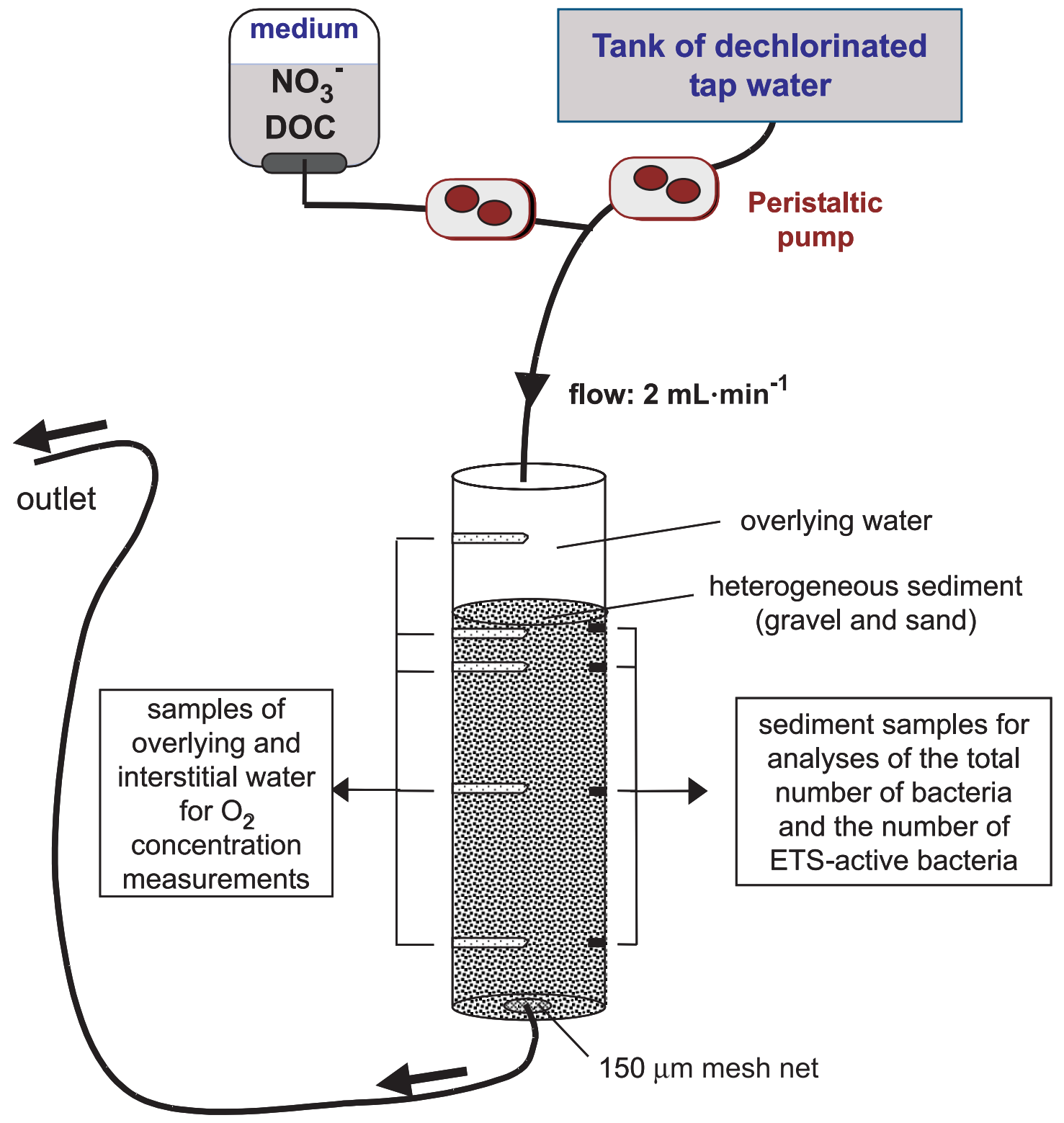

6500, and 13000 individuals $\cdot \mathrm{m}^{-2}$ for asellids, chironomids and tubificid worms, respectively. These densities approached those observed in natural gravel-sand sediments of braided channels of the Rhône River (Fruget 1989; Martinet 1993). The organisms were collected at three sites: a dead arm of the Rhône River about $20 \mathrm{~km}$ upstream of Lyon, the Semène River, and the Ardière River. For acclimation to the experimental conditions (sediment grain sizes and food), animals were maintained in the laboratory for more than 30 days before introduction into the microcosms. The first measurements (day 0) confirmed consistency in conditions among the four columns of each experiment before introduction of the invertebrates. After this, invertebrates were introduced in the overlying water of the columns.

Sediment reworking was estimated after 20 days of experimentation. $\mathrm{O}_{2}$ concentrations and bacterial parameters were also measured on day 20. Dissolved $\mathrm{O}_{2}$ concentrations were measured at five depths $(5 \mathrm{~cm}$ above the sediment surface and $1,5,15$, and $35 \mathrm{~cm}$ below the sediment surface), and bacterial parameters (bacterial abundance and numbers of ETS-active bacteria on fine sediment) were evaluated at four depths in the sediment $(1,5,15$, and $35 \mathrm{~cm}$ below the sediment surface).

\section{Methods of analysis}

Sediment reworking in the columns was quantified by the luminophore tracer technique (Gérino 1990). To reproduce the grain size heterogeneity of the sand present in the columns, we used two size fractions of luminophores (natural sediment particles dyed with fluorescent paint): 63 - to $100-\mu \mathrm{m}$ particles (pink) and 100- to 350- $\mu \mathrm{m}$ particles (yellow). On day 0 of each experiment, a mixture of the two fractions $(0.5$ grams per fraction) was deposited at the surface of the sediment of the four columns before invertebrate introduction. After a 20- 
day period, water was removed from all columns and columns were opened to allow sampling of sediment and luminophores. The top $2 \mathrm{~cm}$ of sediment was collected at 0.5 $\mathrm{cm}$ intervals and the next $18 \mathrm{~cm}$ collected at $1-\mathrm{cm}$ intervals. Each layer was homogenized and a 1-g subsample was dried at $50{ }^{\circ} \mathrm{C}$ for luminophore counting. The number of luminophores in each subsample was estimated using an ultraviolet light microscope and converted into grams of tracers per gram of dry sediment.

The effect of invertebrates on particle transport was estimated using the diffusion-advection-nonlocal model in nonsteady-state conditions (Mugnai et al. 2003). This model links a nonlocal component to a diffusion-advection model (Officer and Lynch 1982; Gérino et al. 1994). Biological diffusive transport (diffusion $(D)$, square centimetres per year) was defined as omnidirectional transport in the sediment column and is analogous to molecular diffusion in water. Biodiffusion spreads tracers in the sediment column (Guinasso and Schink 1975) by the exchange of small amounts of material with adjacent parcels of sediment. Most depositfeeding activities result in the vertical transport of material, which cannot be fitted with diffusional models. Biologically mediated vertical transports account for advective transport and nonlocal transport. Bioadvection ( $V$, centimetres per year) is created by head-down deposit-feeders like worms that feed in the deeper sediment and egest fecal pellets at the surface (conveyor belt organisms). This feeding mode causes an accelerated rate of sediment and pore water burial within the feeding zone. Nonlocal transport results from largely open burrows into which surface particles may fall, and this type of vertical transport is much more rapid than bioadvection. This nonlocal mixing is modeled as a removal function that simulates the deposition of surface material (expressed in grams of transported tracer per day) in a deposition zone. The basic equation is

$$
\frac{\partial C(z, t)}{\partial t}=D \frac{\partial^{2} C(z, t)}{\partial z^{2}}-V \frac{\partial C(z, t)}{\partial z}+K(z, t)-R(z, t)
$$

where $C$ is the normalized tracer concentration, $t$ is time (years), $z$ is depth (centimetres), $D$ is the diffusive mixing rate (square centimetres per year), $V$ is the advective transport rate (centimetres per year), $R$ is the removal function that determines the mass of tracer (grams per day) removed from the surface and $K$ is the injection function of the nonlocal transport that simulates tracer inputs (grams per day) into the injection zone of the sediment column; $K_{\mathrm{e}}$ is a constant parameter (per day) estimated from the model, and depths $Z_{\min }$ and $Z_{\max }$ represent the upper and lower limits of the injection zone, respectively. The nonlocal transport is thus quantified by a flux of sediment removed from the surface. In this case, $R(z, t)=0$ for $z>0$ and $R(z, t)=K(z, t)$ $\left(Z_{\max }-Z_{\min }\right)$ for $z=0$ and $K(z, t)=K_{\mathrm{e}}$ for $\left.z \in Z_{\min }, Z_{\max }\right]$ and $K(z, t)=0$ for $z \notin\left[Z_{\min }, Z_{\max }\right]$.

Luminophores were added as pulse input at the surface of the sediment at the beginning of each experiment so that the model was applied under non-steady-state conditions. Thus, model eq. 1 was used with the upper boundary condition of an instantaneous source of unit strength (maximal $C$ of tracer) at $z=0$ at $t=0$, a lower boundary $C \rightarrow 0$ at $z \rightarrow \infty$, and ini- tial condition $C=0$ at $z>0$. The general solution was given by Officer and Lynch (1982) as

$$
\begin{aligned}
C(z, t)= & \frac{1}{\sqrt{\pi D t}} \exp \left[-\frac{(z-V t)^{2}}{4 D t}\right] \\
& -\frac{V}{2 D} \exp \left(\frac{V z}{2 D}\right) \operatorname{erfc}\left(\frac{z+V t}{\sqrt{4 D t}}\right)-R_{\mathrm{e}} t+K_{\mathrm{e}} t
\end{aligned}
$$

with

$$
R_{\mathrm{e}}=K_{\mathrm{e}}\left(Z_{\max }-Z_{\min }\right)
$$

and

$$
\operatorname{erfc}(x)=1-\frac{2}{\sqrt{\pi}} \int_{0}^{x} \mathrm{e}^{-t^{2}} \mathrm{~d} t
$$

where $c$ is a normalized concentration relative to unit input. The model allows the calculation of the theoretical tracer concentration given suitable values of the parameters $D, V$, $Z_{\min }, Z_{\max }$, and $K_{\mathrm{e}}$. These parameters were obtained from profiles that produced the best fit with the experimental data using the least squares method.

$\mathrm{O}_{2}$ concentration was measured with the technique developed by Mermillod-Blondin et al. (2000a). At each depth, $30 \mathrm{~mL}$ of water was collected in a $\mathrm{N}_{2}$ sparged bottle. This water circulated at a rate of $20 \mathrm{~mL} \cdot \mathrm{min}^{-1}$ through an Orbisphere-type respirometer chamber equipped with a Clarke-type electrode connected to an Orbisphere oxymeter (model 3600). This procedure allowed the measurement of dissolved $\mathrm{O}_{2}$ concentrations in the samples without contact with atmospheric $\mathrm{O}_{2}$.

The total number of bacteria was estimated by epifluorescence after 4',6-diamidino-2-phenylindole (DAPI) staining (Porter and Feig 1980). Wet sediment (0.3-0.5 g) was suspended in $40 \mathrm{~mL}$ of filtered (on a $0.2-\mu \mathrm{m}$ acetate membrane) distilled water and $10 \mathrm{~mL}$ of a solution of pyrophosphate $\left(0.002 \mathrm{~mol} \cdot \mathrm{L}^{-1}\right.$ final concentration) by sonication (Bioblock Vibracell 72041; for 180 s, power 2, duty cycle $50 \%$ ). One millilitre of the suspension was filtered through a GF/D Whatman filter (mean pore size $2.7 \mu \mathrm{m}$ ) to eliminate the coarsest particles. Staining was performed by addition of $0.1 \mathrm{~mL}$ of DAPI solution $\left(100 \mu \mathrm{g} \cdot \mathrm{L}^{-1}\right)$ to $1 \mathrm{~mL}$ of the filtrate. After $10 \mathrm{~min}$ of incubation, the suspension was filtered on a GTBP Millipore membrane (mean pore size $0.2 \mu \mathrm{m}$ ), which was then washed, air-dried, and mounted in low-fluorescence immersion oil on a microscope glass slide. Bacterial counts were performed using an epifluorescence microscope (Zeiss microscope fitted with a $200-\mathrm{W}$ mercury burner and a Zeiss 365-nm excitation filter). At least 30 randomly selected fields were counted per slide. Results were expressed as numbers of bacteria per gram of dry sediment.

The number of bacteria with an active ETS (ETS-active bacteria) was measured using 5-cyano-2,3-ditolyltetrazolium chloride staining (Rodriguez et al. 1992). Wet sediment (0.3-0.5 g) was incubated with a $1.38 \mathrm{mg}$ 5-cyano-2,3-ditolyltetrazolium chloride $\cdot \mathrm{L}^{-1}$ solution (final concentration) for $3 \mathrm{~h}$ at $20{ }^{\circ} \mathrm{C}$ and then sonicated using the same procedure as for DAPI with a dilution in $20 \mathrm{~mL}$ of pyrophosphate solution. Five millilitres of the suspension was processed and slides pre- 
Fig. 2. Depth profiles (means $\pm \mathrm{SD}$ ) of luminophores (circles) in the eight treatments and calculated profiles (diamonds) obtained with the advection-diffusion-nonlocal model and the average coefficients of transport. Animal treatments: A, 25 asellids; C, 50 chironomids; T, 100 tubificid worms; A+C, 25 asellids +50 chironomids; A+T; 25 asellids +100 tubificid worms; C+T, 50 chironomids + 100 tubificid worms; A+C+T, 25 asellids +50 chironomids +100 tubificid worms.

\section{Percentage of luminophores (\%)}
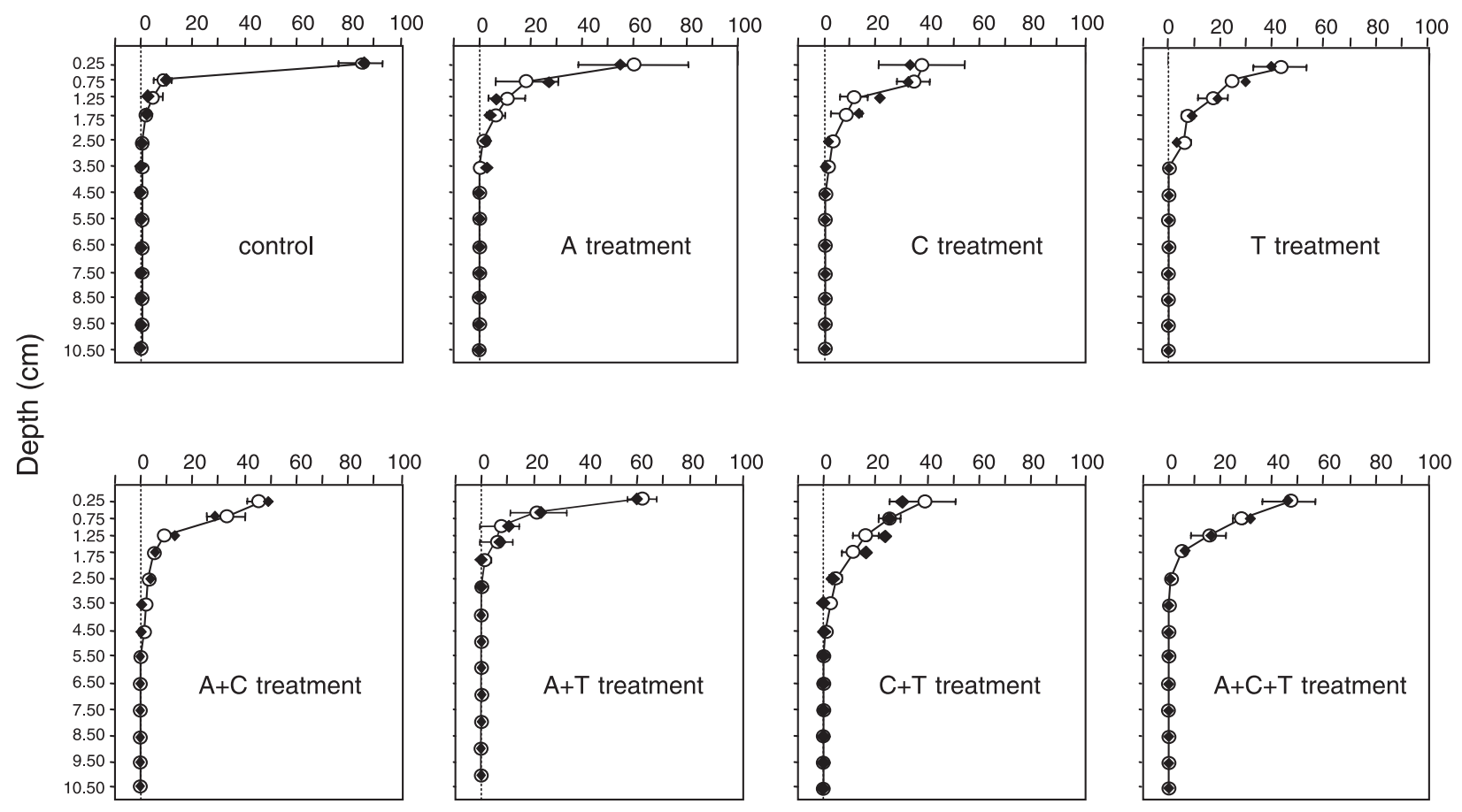

Table 1. Mixing rates of sediment estimated in the eight treatments.

\begin{tabular}{llllll}
\hline Treatment & $\begin{array}{l}\text { Advection } \\
\left(\mathrm{cm} \cdot \mathrm{year}^{-1}\right)\end{array}$ & $\begin{array}{l}\text { Diffusion } \\
\left(\mathrm{cm}^{2} \cdot \mathrm{year}^{-1}\right)\end{array}$ & $\begin{array}{l}\text { Nonlocal transport } \\
\left(\mathrm{g} \cdot \mathrm{day}^{-1}\right)\end{array}$ & $Z_{\min }(\mathrm{cm})$ & $Z_{\max }(\mathrm{cm})$ \\
\hline Control & $0(0)$ & $1.06(0.26)$ & $0.013(0.011)$ & $0.875(0.48)$ & $1.875(0.25)$ \\
A & $0(0)$ & $3.3(2.3)$ & $0.043(0.020)$ & $1.27(0.46)$ & $3.73(1.27)$ \\
$\mathrm{C}$ & $0(0)$ & $8.23(6.82)$ & $0.068(0.035)$ & $0.67(0.29)$ & $2.33(1.53)$ \\
$\mathrm{T}$ & $0(0)$ & $7.8(5.4)$ & $0.023(0.002)$ & $0.83(0.29)$ & $3(0)$ \\
$\mathrm{A}+\mathrm{C}$ & $0(0)$ & $4.23(0.25)$ & $0.047(0.012)$ & $0.83(2.9)$ & $3.33(2.08)$ \\
$\mathrm{A}+\mathrm{T}$ & $0(0)$ & $2.4(0.85)$ & $0.040(0.057)$ & $1(0)$ & $2(0)$ \\
$\mathrm{C}+\mathrm{T}$ & $0(0)$ & $13.13(14.66)$ & $0.036(0.029)$ & $1(0.5)$ & $2.17(0.76)$ \\
$\mathrm{A}+\mathrm{C}+\mathrm{T}$ & $0(0)$ & $6.0(2.16)$ & $0.011(0.001)$ & $1(0)$ & $2.17(0.76)$ \\
\hline
\end{tabular}

Note: Advective, diffusive, and nonlocal transport coefficients are presented as means (SD) $(n=7$ for control and $n$ $=3$ for animal treatments). $Z_{\min }$ and $Z_{\max }$ are the respective upper and lower limits of the sediment layer influenced by nonlocal transport. Animal treatments: A, 25 asellids; C, 50 chironomids; T, 100 tubificid worms; A+C, 25 asellids + 50 chironomids; $\mathrm{A}+\mathrm{T} ; 25$ asellids +100 tubificid worms; $\mathrm{C}+\mathrm{T}, 50$ chironomids +100 tubificid worms; $\mathrm{A}+\mathrm{C}+\mathrm{T}, 25$ asellids +50 chironomids +100 tubificid worms.

pared using the procedure for DAPI samples. Bacteria were counted with an epifluorescence microscope fitted with a 200-W mercury burner, a blue 420-nm excitation filter (Zeiss model BP 390-420), and a 540-nm barrier filter (Zeiss model LP 540). At least 30 randomly selected fields were counted per slide. Results were expressed as numbers of bacteria per gram of dry sediment.

At the end of each experiment, the living invertebrates were enumerated at three layers (0-10, 10-20, and 20-40 cm depth) of each column. The numbers of collected invertebrates were used to estimate the animal mortality and to provide information about the vertical distribution of invertebrates in columns.

\section{Data treatment}

\section{Effect of each animal treatment}

The data obtained in control columns of the seven experiments were combined in the statistical analyses. The sediment reworking coefficients obtained from the eight treatments were $\ln (x+1)$ transformed to homogenize variances. Differences in transformed reworking coefficients were tested using a oneway analysis of variance (ANOVA). Bonferroni-Dunn post hoc tests were performed if significance was detected to determine which treatments differed. For each column, the $\mathrm{O}_{2}$ concentrations measured in sediments were expressed as percentages of 
the value measured in the overlying water (= dissolved $\mathrm{O}_{2}$ in water supplied to the column, mean values \pm SD: $5.92 \pm$ $\left.0.24 \mathrm{mg} \cdot \mathrm{L}^{-1}\right)$. In the analyses, the total number of bacteria and the number of ETS-active bacteria were log transformed. The effects of animals on $\mathrm{O}_{2}$ concentrations and numbers of bacteria measured on day 20 were compared using a two-way ANOVA with treatment and depth as main effects (Statistica $5^{\text {TM}}$; Statsoft, Tulsa, Oklahoma). Bonferroni-Dunn post hoc tests were performed to determine which treatments differed. Numbers of living invertebrates found at the end of the experiments were expressed as percentages. We compared the percentages of living animals between animal treatments using a one-way ANOVA. The numbers of animals found at the three sampling layers were also expressed as percentages. We tested the taxa and depth effects on invertebrate distributions using a two-way ANOVA with taxa and depth as main effects. Variables expressed as percentages (microbial variables) were arcsine transformed (Sokal and Rohlf 1995).

\section{Impact of mixture in comparison with individual effects (measure of interactions)}

Comparisons of effects of two- or three-taxa mixtures with effects of invertebrates in isolation were made by comparing sediment reworking coefficients, $\mathrm{O}_{2}$ concentrations, and microbial variables in animal and control columns. Using single-taxon effects, we used an additive model similar to those described by Raffaelli et al. (2003, p. 137) against which we compared observed multitaxa effects. The interactions were measured as the differences between the observed effects with two- or three-taxa mixtures and the predicted effects of mixtures calculated by all combinations of the effects of the taxon in isolation (individual effects). For example, in the case of the $\mathrm{A}+\mathrm{C}$ treatment, values calculated using the additive model $(n=9,3$ columns $\times 3$ columns $)=$ $E(\mathrm{~A})_{n=3}+E(\mathrm{C})_{n=3}$ were compared with observed values $(n=$ $3)=E(\mathrm{~A}+\mathrm{C})_{n=3}$, where $E(\mathrm{~A})$ and $E(\mathrm{C})$ are asellid effect and chironomid effects in one-taxon experiments and $E(\mathrm{~A}+\mathrm{C})$ is the value measured in the $\mathrm{A}+\mathrm{C}$ experiment. With this method, we expected that, in the absence of interactions, the effects of 50 chironomids and the effects of 25 asellids would be simply added in the treatment with 50 chironomids +25 asellids. Using this additive model, we assumed that effects measured in mixtures were linked to interactions between taxa rather than a simple effect of animal density. Because the impact of each invertebrate taxon in sediment was linked to its life mode (Mermillod-Blondin et al. 2002), the type of effect (production of tubes or galleries, sediment reworking mode) produced by a taxon in sediment was not expected to be strongly affected by its density. For $\mathrm{O}_{2}$ concentrations and microbial variables, observed and predicted values were compared using a two-way ANOVA with observed-predicted and depth as main effects. For coefficients of sediment reworking, observed and predicted values were compared using Student $t$ tests. A significant (negative or positive) difference indicates that interactions between taxa modified the system functioning because the effects of the two or three taxa were not reported in mixture treatments. In addition, it could be observed that the dominant effect of one taxon in mixtures can lead to the detection of significant interactions. Thus, the effects of mixtures were compared with the effects of
Fig. 3. Coefficients (means $\pm \mathrm{SD}$ ) of $(a)$ biodiffusion and (b) nonlocal transport (expressed as $\ln (x+1)$ ) measured in the eight treatments (open bars). Predicted coefficients (shaded bars) are indicated for the two- and three-taxa treatments. Animal treatments: A, 25 asellids; C, 50 chironomids; T, 100 tubificid worms; $\mathrm{A}+\mathrm{C}, 25$ asellids +50 chironomids; $\mathrm{A}+\mathrm{T} ; 25$ asellids +100 tubificid worms; $\mathrm{C}+\mathrm{T}, 50$ chironomids +100 tubificid worms; $\mathrm{A}+\mathrm{C}+\mathrm{T}, 25$ asellids +50 chironomids +100 tubificid worms.
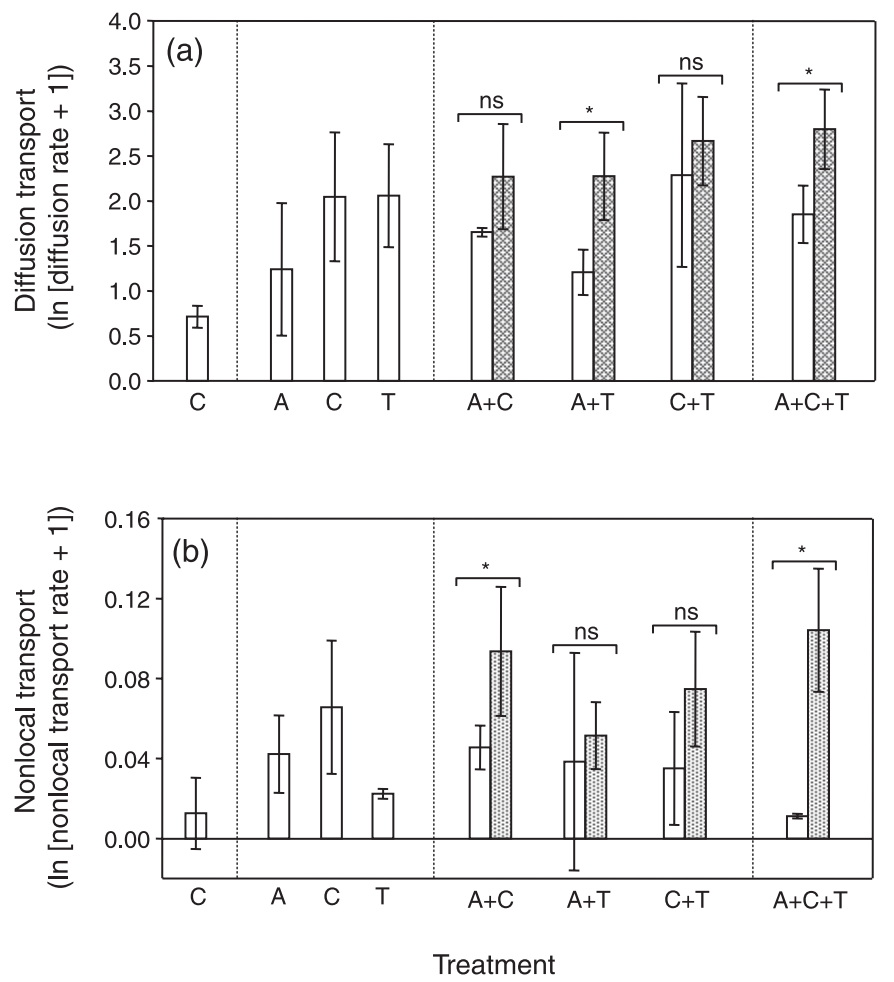

each taxon forming the mixture to determine if one taxon present in the mixture drove the system functioning. Statistical tests used to compare mixture effects and one-taxon effects were the same as those used for observed-predicted comparisons.

\section{Results}

\section{Effects of animal treatments}

The luminophore profiles obtained at the end of the experiments showed that the average percentage of tracer measured at the sediment surface $(0-0.5 \mathrm{~cm}$ layer) was the highest in the control columns $(87 \%)$ and varied from $62 \%$ to $38 \%$ in invertebrate treatments (Fig. 2). With the exception of chironomid treatment, the profiles were characterized by a rapid decrease of tracer with depth, indicating a biodiffusive reworking of sediment. With chironomids, similar concentrations of luminophore were measured in the $0-0.5$ and $0.5-$ $1 \mathrm{~cm}$ layers. This result was attributed to a nonlocal transport of the tracer from the surface to the $0.5-1 \mathrm{~cm}$ layer. Model data fit experimental data well (Fig. 2). The coefficients of sediment reworking from model simulations are shown in Table 1. No bioadvection was observed in the treatments. The biodiffusion coefficient varied significantly among treatments (Fig. 3; Table 2). With the exception of 
Table 2. ANOVAs for the comparison among treatments (and depth for two-way ANOVA) on coefficients of sediment reworking, $\mathrm{O}_{2}$ concentrations, and microbial parameters.

\begin{tabular}{llrrr}
\hline Variable & Source & df & $F$ & $p$ \\
\hline One-way ANOVA & & & & \\
Biodiffusion of surface particles & Treatment & 7 & 4.6 & $<0.05$ \\
& Error & 19 & & \\
Nonlocal transport of surface particles & Treatment & 7 & 2.4 & $>0.05$ \\
& Error & 19 & & \\
Two-way ANOVA & & & & \\
O $_{2}$ & Treatment & 7 & 19.7 & $<0.001$ \\
& Depth & 3 & 306.3 & $<0.001$ \\
& Treatment $\times$ depth & 21 & 3.8 & $<0.001$ \\
Total number of bacteria & Error & 80 & & \\
& Treatment & 7 & 4 & $<0.001$ \\
& Depth & 3 & 257.1 & $<0.001$ \\
& Treatment $\times$ depth & 21 & 4.3 & $<0.001$ \\
Number of ETS-active bacteria & Error & 80 & & \\
& Treatment & 7 & 12.1 & $<0.001$ \\
& Depth & 3 & 408.2 & $<0.001$ \\
& Treatment $\times$ depth & 21 & 3.5 & $<0.001$ \\
& Error & 80 & & \\
\hline
\end{tabular}

Table 3. Effects of each animal treatment on coefficients of sediment reworking, $\mathrm{O}_{2}$ concentrations, and microbial characteristics (comparison with the control treatment).

\begin{tabular}{llllllll}
\hline & \multicolumn{7}{l}{ Animal treatment } \\
\cline { 2 - 8 } Variable & $\mathrm{A}$ & $\mathrm{C}$ & $\mathrm{T}$ & $\mathrm{A}+\mathrm{C}$ & $\mathrm{A}+\mathrm{T}$ & $\mathrm{C}+\mathrm{T}$ & $\mathrm{A}+\mathrm{C}+\mathrm{T}$ \\
\hline Biodiffusion & 0 & + & + & + & 0 & + & + \\
Nonlocal transport & 0 & + & 0 & + & 0 & 0 & 0 \\
Effect on $\mathrm{O}_{2}$ concentrations & + & + & - & - & - & - & - \\
Effect on total number of bacteria & 0 & 0 & + & 0 & + & 0 & + \\
Effect on ETS-active bacteria & 0 & - & + & + & + & + & + \\
\hline
\end{tabular}

Note: Bonferroni-Dunn test with $n=3$ for invertebrate treatments and $n=7$ for the control. 0 , no significant difference; +, significant increase; - , significant decrease owing to the invertebrates. Animal treatments: A, 25 asellids; C, 50 chironomids; T, 100 tubificid worms; A+C, 25 asellids +50 chironomids; A+T; 25 asellids +100 tubificid worms; $\mathrm{C}+\mathrm{T}, 50$ chironomids +100 tubificid worms; $\mathrm{A}+\mathrm{C}+\mathrm{T}, 25$ asellids +50 chironomids +100 tubificid worms.

the $\mathrm{A}$ and the $\mathrm{A}+\mathrm{T}$ treatments, all invertebrate assemblages significantly increased the diffusion of surface sediment within the porous media (Table 3). No significant difference in nonlocal transport was measured among the different treatments (Table 2). However, $\mathrm{C}$ and $\mathrm{A}+\mathrm{C}$ treatments had significantly higher nonlocal transport rates than the control (Table 3).

Whatever the treatment, $\mathrm{O}_{2}$ concentration decreased with depth in all columns and this decrease was the highest in the top $5 \mathrm{~cm}$ of sediment (Fig. 4; Table 2). Significant decreases in total number of bacteria and number of ETS-active bacteria with depth were also observed in columns (Figs. 5 and 6; Table 2). For all variables, significant differences were measured among treatments. The $\mathrm{A}$ and the $\mathrm{C}$ treatments significantly increased the $\mathrm{O}_{2}$ concentrations (Table 3 ). In contrast, the other animal treatments significantly reduced $\mathrm{O}_{2}$ concentrations in the sediment. These significant differences depended on depth (two-way ANOVA, interaction taxa-depths) (Table 2), as most animal treatments had significantly higher effects in the top $5 \mathrm{~cm}$ of sediments. The same patterns were observed in number of ETS-active bacteria: all animal treat- ments significantly increased the number of active bacteria except the A treatment, which had no significant effect, and the $\mathrm{C}$ treatment, which reduced this bacterial variable in sediments. Like ETS-active bacteria, the total abundance of bacteria significantly decreased with depth and was different among treatments. The A treatment and $\mathrm{C}$ treatments had no significant effect on this variable. However, unlike results obtained with $\mathrm{O}_{2}$ measurements and abundances of ETSactive bacteria, all of the other treatments did not increase the number of bacteria in the sediment $(\mathrm{A}+\mathrm{C}$ and $\mathrm{C}+\mathrm{T}$ treatments had no significant effects on this variable (Table 3 )).

The results also showed that the variabilities among the effects of one-taxon treatments were higher than those obtained among multitaxa treatments (Table 3). For $\mathrm{O}_{2}$ concentrations, the three one-taxon treatments did not have the same effect (increase or decrease of $\mathrm{O}_{2}$ concentrations), whereas the same response of the system (a decrease of $\mathrm{O}_{2}$ concentrations) was measured in all two- and three-taxa treatments. All two- and three-taxa treatments also produced a significant increase in the number of ETS-active bacteria. In contrast, with one taxon, increases or decreases in ETS- 
Fig. 4. Depth profiles (means $\pm \mathrm{SD}$ ) of $\mathrm{O}_{2}$ concentrations in the eight treatments. The depth profile of the control treatment (open circles) is reported on all graphs with each animal treatment (solid circles). Animal treatments: A, 25 asellids; C, 50 chironomids; T, 100 tubificid worms; A+C, 25 asellids +50 chironomids; A+T; 25 asellids +100 tubificid worms; $\mathrm{C}+\mathrm{T}, 50$ chironomids +100 tubificid worms; A+C+T, 25 asellids +50 chironomids +100 tubificid worms.

\section{Dissolved oxygen concentration expressed as \% of the oxygen supply}
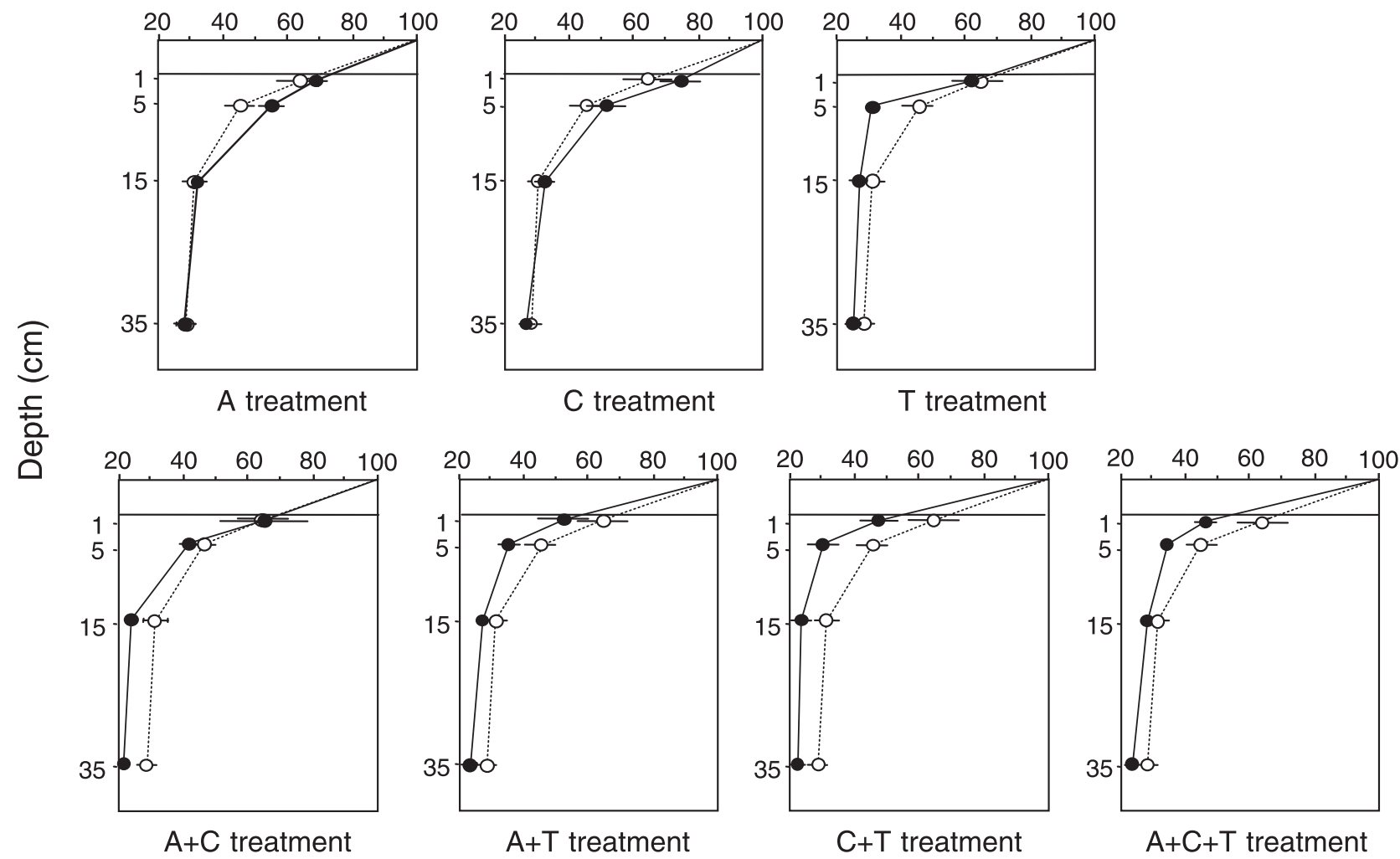

\section{Treatment}

active bacteria abundances were observed depending on the taxon tested.

\section{Estimation of the interactions between taxa}

For both diffusion and nonlocal transport, the reworking coefficients measured in mixtures were in the range of values measured in one-taxon treatments (Fig. 3). However, the measured coefficients in mixtures tended to be lower than the predicted coefficients calculated from individual effects of the taxa. Significantly lower coefficients of biodiffusion were measured in $\mathrm{A}+\mathrm{T}$ and $\mathrm{A}+\mathrm{C}+\mathrm{T}$ treatments in comparison with predictions. The nonlocal transports of surface sediment measured in the $\mathrm{A}+\mathrm{C}$ and $\mathrm{A}+\mathrm{C}+\mathrm{T}$ treatments were significantly lower than those predicted.

Whatever the invertebrate mixture, all treatments produced significantly higher decreases in $\mathrm{O}_{2}$ concentration than those predicted with the additive model (Fig. 7a). The effects of the $\mathrm{A}+\mathrm{C}$ treatment decreased $\mathrm{O}_{2}$ concentrations in columns, whereas $\mathrm{A}$ and $\mathrm{C}$ treatments had the opposite effect. Therefore, the mixture of asellids and chironomids created a significantly different effect than expected and the single-taxon effects (two-way ANOVA, measured data in mixture versus measured data in one-taxon treatments, $p<0.01$ ). For the mixtures with tubificid worms, the $\mathrm{O}_{2}$ concentrations were always lower at $1 \mathrm{~cm}$ depth in the mixture than in one-taxon treatments (two-way ANOVA, measured data versus calculated data and measured data in one-taxon treatments, $p<$ 0.01 ) and significant differences between predicted and observed values in mixtures were detected (Fig. 7a).

In contrast, the interaction between taxa did not provide significant differences in bacterial abundances (total numbers and numbers of ETS-active bacteria) (Figs. $7 b$ and 7c), except the interaction between chironomids and tubificids, which significantly increased the number of ETS-active bacteria in sediments (two-way ANOVA, measured data versus calculated data, $p<0.05)$. High variability in bacterial counting clearly limited statistical power. For instance, although the $\mathrm{A}+\mathrm{C}$ treatment tended to increase the number of ETSactive bacteria at 5 and $15 \mathrm{~cm}$ depth, while calculated values showed the opposite trend, no significant difference between measured and predicted values was observed.

\section{Estimated mortality and distribution of invertebrates at the end of the experiments}

Whatever the invertebrate assemblage tested, the percentage of living invertebrates varied from $77 \%$ to $92 \%$ and was not significantly different among treatments (one-way ANOVA, $p=0.11$ ) (Table 4). The number of invertebrates found at 
Fig. 5. Depth profiles (means $\pm \mathrm{SD}$ ) of $\log _{10}$ (total number of bacteria) in the eight treatments. The depth profile of the control treatment (open bars) is reported on all graphs with each animal treatment (solid bars). Animal treatments: A, 25 asellids; C, 50 chironomids; T, 100 tubificid worms; A+C, 25 asellids +50 chironomids; A+T; 25 asellids +100 tubificid worms; C+T, 50 chironomids + 100 tubificid worms; A+C+T, 25 asellids +50 chironomids +100 tubificid worms.

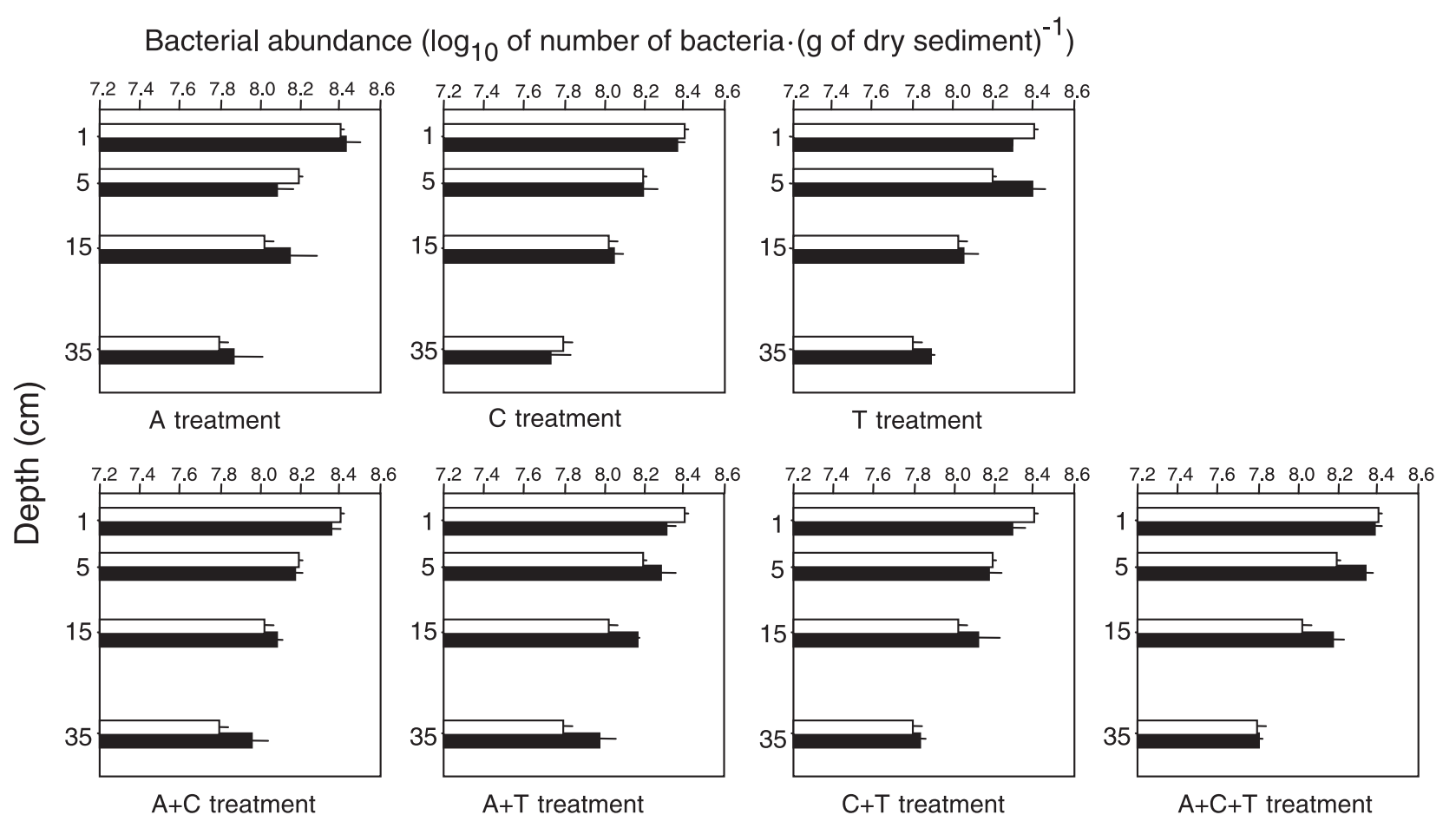

\section{Treatment}

each layer of sediment showed that most animals (>90\%) were observed in the first $10 \mathrm{~cm}$ of sediment (two-way ANOVA, depth effect, $p<0.001)$. Furthermore, no significant differences were measured in the vertical distribution of each taxon among treatments.

\section{Discussion}

\section{Individual effects of the three taxa}

In the river sediments, the three taxa showed significantly different bioturbation activities: asellids had no significant effect on surface sediment distribution, tubificid worms increased the biodiffusion of surface particles, and chironomids enhanced both biodiffusion and nonlocal transport of surface sediment in the porous media. As described in a previous study (Mermillod-Blondin et al. 2003), the pore water flow in sediment columns was characterized by a $50 \%$ mobile water phase in macropores (where water flow took place by advection), a $50 \%$ immobile phase in sandy zones (where water flow took place by diffusion), and an exchange coefficient of $0.15 \cdot \mathrm{h}^{-1}$ between the mobile and immobile phases. Several studies (Molz et al. 1986; Murphy et al. 1997; Thullner et al. 2002) have shown that microbial activities are linked to $\mathrm{O}_{2}$ and nutrient transport in porous media. Thus, the modification of hydrodynamics by bioturbation was expected to affect microbial characteristics in the experimental system. As a consequence, the distinct bioturbation processes performed by the three taxa may have modified hydrodynamics and nutrients availability for microorganisms in sedi- ments (Mermillod-Blondin et al. 2002). The nonlocal transport of surface sediment produced by chironomids was due to the presence of tubes inserted into the sediments. The $\mathrm{O}_{2}$ measurements showed that these tubes opened macropores through the sediment, which favoured a rapid transfer of $\mathrm{O}_{2}$ to the deeper layers by concentrating the flow through pores (reducing the contact between mobile and immobile phases of water flow). This effect on water transport reduced the nutrient availability for bacteria in sandy zones and decreased microbial activity outside these pores, as indicated by the decrease in the number of ETS-active bacteria in chironomid treatment. The lack of surface sediment reworking by asellids was probably linked to their use of sediments restricted to the subsurface zone $(1-3 \mathrm{~cm})$, as demonstrated by Mermillod-Blondin et al. (2002). Despite a low redistribution of surface sediment by asellids, the sediment reworking in subsurface might have created macropores that concentrated the downward flow of water. As supposed for chironomid action, this change in hydrodynamics would reduce the contact time between water and the sandy zone and lead to the increase in $\mathrm{O}_{2}$ concentrations measured in the foraging zone of asellids ( $0-5 \mathrm{~cm}$ below the sediment surface). In one-taxon experiments, the effect of tubificid worms on $\mathrm{O}_{2}$ concentration was the opposite of that of the other two taxa. In contrast with asellids and chironomid larvae, which created macropores that limited the exchange of infiltrated water with sandy zones, tubificid worms built a dense network of galleries and ejected fecal pellets at the sediment surface (Mermillod-Blondin et al. 2001), producing increased 
Fig. 6. Depth profiles (means $\pm \mathrm{SD}$ ) of $\log _{10}$ (number electron transport system (ETS)-active bacteria) in the eight treatments. The depth profile of the control treatment (open bars) is reported on all graphs with each animal treatment (solid bars). Animal treatments: A, 25 asellids; C, 50 chironomids; T, 100 tubificid worms; A+C, 25 asellids +50 chironomids; A+T; 25 asellids +100 tubificid worms; C+T, 50 chironomids +100 tubificid worms; $\mathrm{A}+\mathrm{C}+\mathrm{T}, 25$ asellids +50 chironomids +100 tubificid worms.

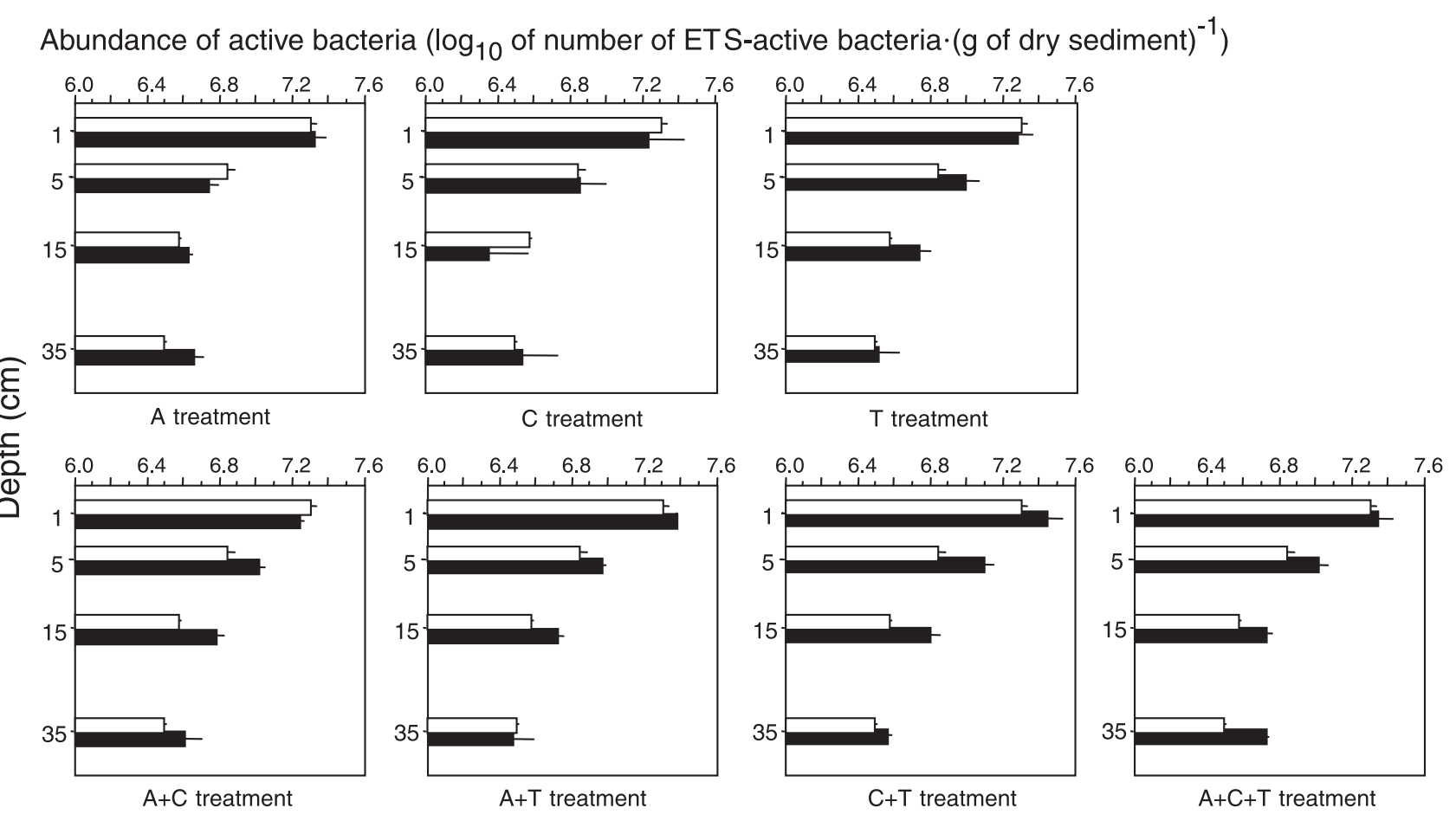

Treatment

exchanges between mobile and immobile phases of water, which stimulated microbial activities in the sediment.

\section{Effect of interactions on system functioning}

The results of sediment reworking and $\mathrm{O}_{2}$ measurements support the hypothesis that the mixture effect was not the sum of the individual effects of the taxa tested in the mixture. This lack of additive process was not due to the dominance of certain taxon in mixtures because mixture treatments always produced lower $\mathrm{O}_{2}$ concentrations than predicted and observed in one-taxon treatments. These results suggest that interactions between taxa have strong effects on the functioning of the water-sediment interface. The sediment reworking induced by the assemblage of two taxa was mostly lower than the predicted one calculated with the additive model. These significant interactions measured between taxa on bioturbation processes probably resulted from a spatial competition among the three taxa, which lived and foraged in the same habitat $(>90 \%$ of animals were found in the first $10 \mathrm{~cm}$ of sediment). As a consequence, these modifications of sediment reworking affected water transport and associated microbial activities. For example, $\mathrm{O}_{2}$ concentration, which is an indicator of aerobic microbial activity in the controlled system, showed that interaction in bioturbation processes affected microbial respiration.

The interaction between asellids and chironomid larvae $(\mathrm{A}+\mathrm{C}$ treatment) strongly affected microbial respiration. The association of the two taxa produced an opposite effect $\left(\mathrm{O}_{2}\right.$ decrease in sediments) compared with the $\mathrm{A}$ and $\mathrm{C}$ treatments $\left(\mathrm{O}_{2}\right.$ increase $)$. The sediment reworking experiments showed that nonlocal transport was significantly lower in the assemblage than expected with the additive model. As chironomid tubes were responsible for nonlocal transport, this result suggests that burrowing by asellids destroyed the tubes produced by chironomids (Fig. 8). Therefore, this interaction may have limited the occurrence of continuous macropores in the sediment matrix, which was observed when each taxon was tested separately. The bioturbated zone produced by the assemblage of chironomids and asellids acted as a finesediment filter, increasing the dispersion of the water in the heterogeneous sediment and stimulating $\mathrm{O}_{2}$ utilization by bacteria in the top $5 \mathrm{~cm}$ of sediment (according to $\mathrm{O}_{2}$ decreases). The opposite effects observed in the $\mathrm{A}+\mathrm{C}$ treatment in comparison with the $\mathrm{A}$ and the $\mathrm{C}$ treatments indicate that interactions between taxa can mask the specific role of each taxon. As a consequence, the assessment of the interaction between taxa is necessary to determine the role of invertebrate assemblages in river sediment processes.

As in the $\mathrm{A}+\mathrm{C}$ treatment, the interactions between chironomids and tubificid worms strongly increased the aerobic microbial respiration (decrease in $\mathrm{O}_{2}$ ) in the first centimetre of sediment. At this depth, $\mathrm{O}_{2}$ concentration and ETS-active bacteria were the opposite of the effects observed with $\mathrm{C}$ and $\mathrm{T}$ treatments and the effects predicted by the additive model. Although there were no significant differences in sediment reworking between observed and predicted effects 
Fig. 7. Measured (open circles and bars) and predicted (shaded circles and bars) effects (means $\pm \mathrm{SD}, n=3$ ) of the two- and threetaxa assemblages on depth profiles of $(a) \mathrm{O}_{2}$ concentrations, $(b)$ total number of bacteria, and $(c)$ numbers of electron transport system (ETS)-active bacteria. The results of the statistical comparison between observed and predicted values are indicated on the graphs (observed-predicted: **, significant difference; ns, no significant difference). Animal treatments: A+C, 25 asellids +50 chironomids; $\mathrm{A}+\mathrm{T} ; 25$ asellids +100 tubificid worms; $\mathrm{C}+\mathrm{T}, 50$ chironomids +100 tubificid worms; $\mathrm{A}+\mathrm{C}+\mathrm{T}, 25$ asellids +50 chironomids +100 tubificid worms.

(a)
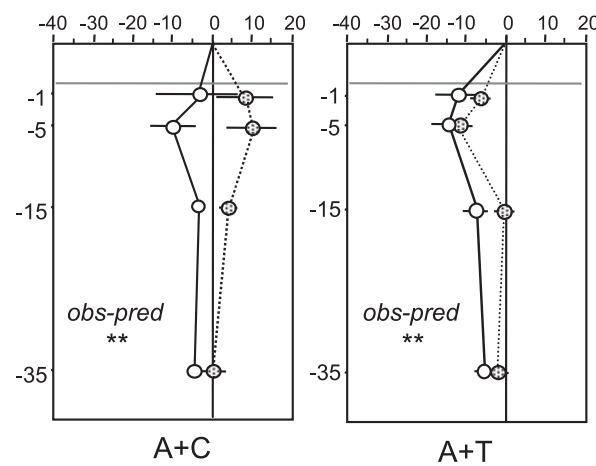

$A+T$
Difference in $\mathrm{O}_{2}$ (\% of the supply)
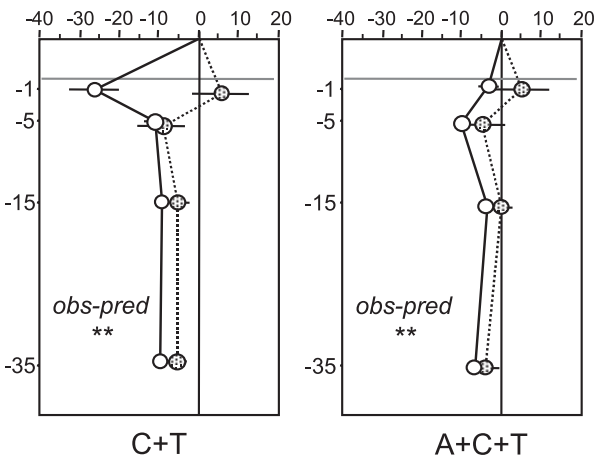

(b) Difference in number of bacteria. (g of dry sediment $)^{-1}\left(\times 10^{8}\right)$
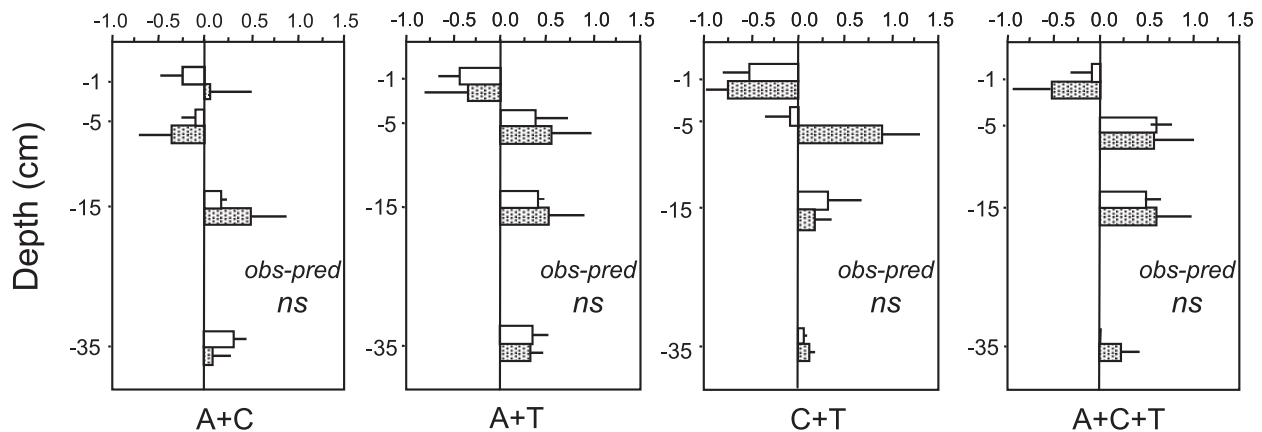

(c) Difference in number of ETS-active bacteria. $(\mathrm{g} \text { of dry sediment })^{-1}\left(\times 10^{7}\right)$

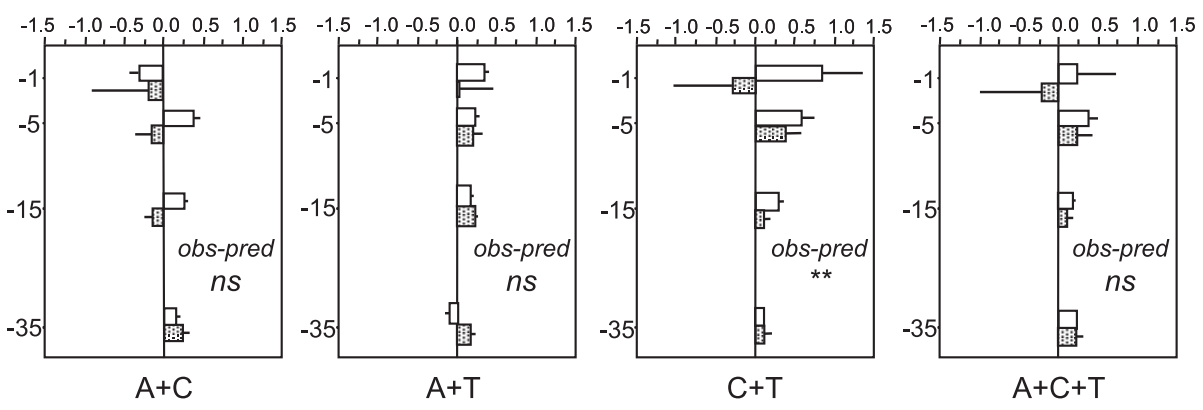

Treatment

of the $\mathrm{C}+\mathrm{T}$ treatment, the mean coefficient of nonlocal transport was twofold lower than the measured coefficient with chironomids and the predicted value. Tubificids produce fecal pellets at the water-sediment interface and we speculate that, in assemblages, fecal pellets deposited by worms filled the macropores produced by chironomid larvae, limiting the continuity of tubes. Therefore, the transport of surface particles within sediments and the rapid downward transfer of $\mathrm{O}_{2}$ through macropores were reduced. The colonization of the fecal pellet surface by bacteria (Yingst and Rhoads 1980) may also have stimulated aerobic respiration in the top $5 \mathrm{~cm}$ of sediment.

The $\mathrm{A}+\mathrm{T}$ and $\mathrm{A}+\mathrm{C}+\mathrm{T}$ treatments also indicated that interaction between taxa affected the bioturbation process (measured coefficients of surface sediment reworking were lower than those predicted) and resulted in increased $\mathrm{O}_{2}$ respiration. 


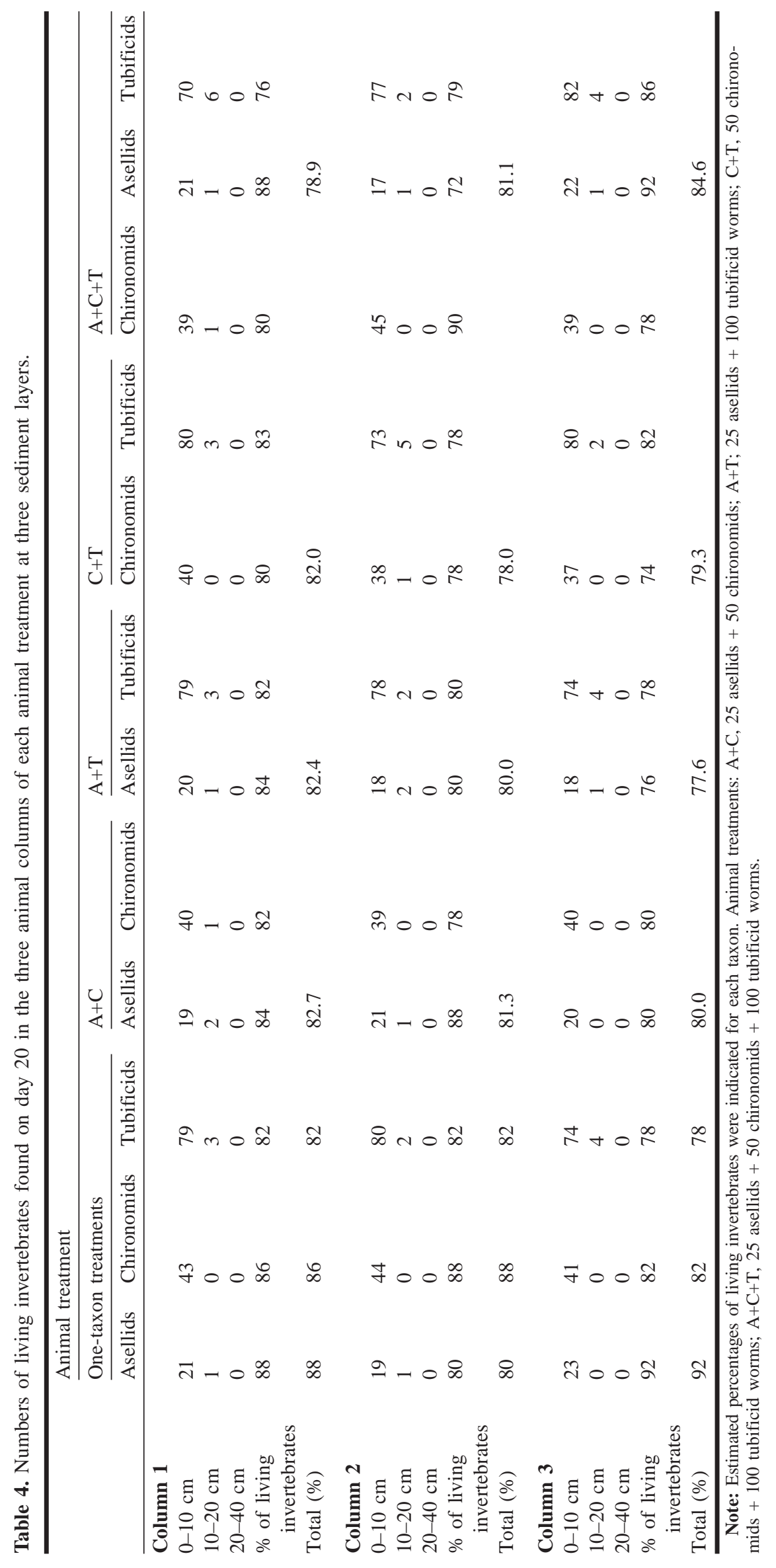


Fig. 8. Schematic representation of the presumed interactions between invertebrates in the two-taxa treatments. This representation does not take into account a possible modification of the behaviour of the taxa when they were associated.

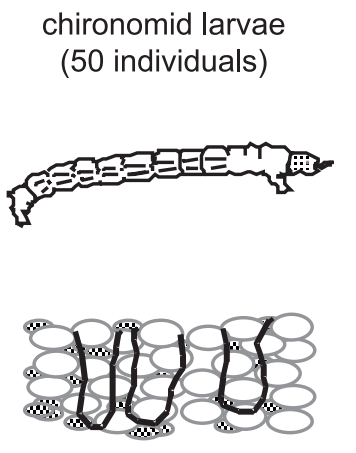

Tube-building (creation of macropores) limiting the dispersion of water flow in the sediment column asellids

(25 individuals)
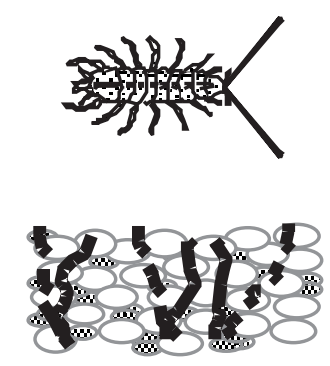

Creation of macropores limiting the dispersion of water flow in the sediment column tubificid worms

(100 individuals)
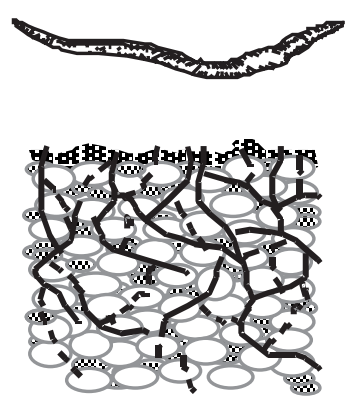

Creation of a gallery network and production of faecal pellets increasing the dispersion of the water flow

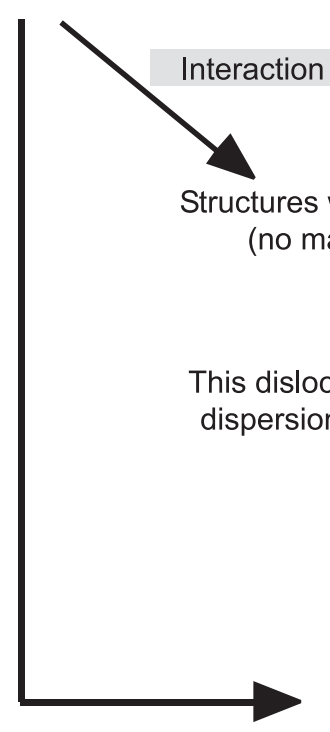

Interaction between structures

The faecal pellets of tubificid worms penetrated into the macropores produced by asellids and chironomid larvae. The tubificid galleries destroyed the macropores.

As explained previously, interactions between built structures (tubes, macropores, galleries, and fecal pellets) may explain the functioning of river sediments (Fig. 8). However, biogenic structure interaction may not be the only explanation. Despite the fact that the distribution of each taxon was not strongly modified by the presence of another taxon, the behaviour of one taxon (type and intensity of bioturbation) may be affected by another taxon and could also modify system processes.

In contrast with coefficients of sediment reworking and $\mathrm{O}_{2}$ measurements, few significant interactions were measured among taxa on microbial variables. This result is probably linked to the high variability in bacterial counting but may also reflect the competing effects of invertebrates on bacteria (Riisgard and Banta 1998): the fauna grazes on biofilm and reduces the bacteria number but also stimulates bacterial

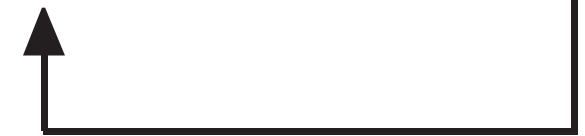

growth rates, increasing the bacterial biomass (gardening effect) and the respiration rate of the microbial community.

\section{Impact of taxa addition on system functioning}

The results indicated that one-taxon treatments might increase (A and $\mathrm{C}$ treatments) or decrease ( $\mathrm{T}$ treatment) $\mathrm{O}_{2}$ concentrations in the sediment as a result of the different activities of fauna (burrowing and moving) in the porous media. In contrast, all two- and three-taxa treatments decreased $\mathrm{O}_{2}$ concentration and stimulated the number of ETS-active bacteria in the sediment. This lower variability measured among two-taxa than among one-taxon treatments was mostly due to the interaction between asellids and chironomids, which created a complete shift in respiration process. Therefore, the fact that interactions between taxa can reduce the variability in several processes supports the assumption that 
functioning variability decreases with taxa number (Naeem and Li 1997). The similar modifications of microbial processes observed with two and three taxa can also be of great importance for the stability of ecosystem functioning. This result suggests that addition of a new taxon did not significantly modify the functioning of a system with two taxa (whatever the characteristics of the added taxon). Because each taxon can tolerate only a limited range of physicochemical and biotic conditions (Tachet et al. 2000), any change in environment (e.g., pollution) beyond these conditions leads to its extinction. Therefore, in the case of environmental changes, the occurrence of three taxa rather than two taxa in the community should provide "insurance" (Chapin et al. 1992; Yachi and Loreau 1999) for the functioning of the sediment-water interface. In other words, a higher number of detritivorous taxa should enhance the probability that the river sediment system will provide a consistent level of performance over a given unit of time. This similar effect of two-taxa and three-taxa treatments also suggests that, beyond a given number of taxa, the physical modification of the system was limited to a threshold level of modification of system functioning (sediment reworking, stimulation of bacteria, and $\mathrm{O}_{2}$ consumption).

\section{Perspectives}

Although our results demonstrated the significant impact that bioturbator interactions have on several river sediment processes, our study used a simplified experimental system with average natural density of each taxon and a limited number of taxa. For example, the impact of density of each taxon and assemblages of taxa on ecosystem functioning has not been tested for all treatments (except for tubificid worms; Mermillod-Blondin et al. 2001) because our additive model supposed that animal density did not strongly affect the impact of asellids or chironomids. The opposite effect of $\mathrm{A}+\mathrm{C}$ treatment on $\mathrm{O}_{2}$ concentration in the top $5 \mathrm{~cm}$ of sediment in comparison with the $\mathrm{A}$ and $\mathrm{C}$ treatments supports our assumption because it is very improbable that bioturbation activities of chironomids and asellids (tube building and reworking of fine sediment) leading to $\mathrm{O}_{2}$ increases would be affected by animal density. However, further investigations using variable densities of each taxon in assemblages should be developed to analyse the possible density-dependent impact on system functioning. Extending the experimental approach developed here to assemblages with much higher species richness is also needed to better understand the links between invertebrate diversity and river sediment functioning.

\section{Acknowledgments}

This work was a part of the programme entitled "Rôle de la diversité des invertébrés à l'interface sédimentaire eaux de surface - eaux souterraines" supported by the French National Centre for Scientific Research (CNRS) (No. 98N62/0144, "Programme Environnement Vie et Sociétés") within the programme "Biodiversité et Fonctionnement des Ecosystèmes (Programme National Dynamique de la Biodiversité et Environnement)". We thank G. Fauvet for his assistance in microbial analyses; J.-L. Reygrobellet and L. Mauclaire for their assistance in collecting invertebrates; and C.P. Henry,
F. Malard, and M.-J. Olivier for reviewing a previous draft of this manuscript.

\section{References}

Battin, T.J., Kaplan, L.A., Newbold, J.D., and Hendricks, S.P. 2003. A mixing model analysis of stream solute dynamics and the contribution of hyporheic zone to ecosystem function. Freshw. Biol. 48: $995-1014$.

Boulton, A.J. 2000. The functional role of the hyporheos. Verh. Int. Ver. Limnol. 27: 51-63.

Boulton, A.J., Findlay, S., Marmonier, P., Stanley, E.H., and Valett, H.M. 1998. The functional significance of the hyporheic zone in streams and rivers. Annu. Rev. Ecol. Syst. 29: 59-81.

Chapin, F.S., Schulze, E.-D., and Mooney, H.A. 1992. Biodiversity and ecosystem processes. Trends Ecol. Evol. 7: 107-108.

Danielopol, D.L. 1989. Groundwater fauna associated with riverine aquifers. J. North Am. Benthol. Soc. 8: 18-35.

Emmerson, M.C., and Raffaelli, D.G. 2000. Detecting the effects of diversity on measures of ecosystem function: experimental design, null models and empirical observation. Oikos, 91: 195-203.

Emmerson, M.C., Solan, M., Emes, C., Paterson, D.M., and Raffaelli, D. 2001. Consistent patterns and the idiosyncratic effects of biodiversity in marine ecosystems. Nature (London), 441: 73-77.

Fruget, J.-F. 1989. L'aménagement du bas-Rhône. Évolution du fleuve et influence sur les peuplements de macro-invertébrés benthiques. Ph.D. thesis, University Lyon-I, France.

Fukuhara, H., and Sakamoto, M. 1987. Enhancement of inorganic nitrogen and phosphate release from lake sediment by tubificid worms and chironomid larvae. Oikos, 48: 312-320.

Gérino, M. 1990. The effects of bioturbation on particle redistribution in Mediterranean coastal sediment - preliminary results. Hydrobiologia, 207: 251-258.

Gérino, M., Stora, G., and Durbec, J.P. 1994. Quantitative estimation of biodiffusive and bioadvective sediment mixing: in situ experimental approach. Oceanol. Acta, 17: 547-554.

Griebler, C. 1996. Some applications for the DMSO-reduction method as a new tool to determine the microbial activity in watersaturated sediments. Arch. Hydrobiol. Suppl. 113: 405-410.

Grimm, N.B., and Fisher, S.G. 1984. Exchange between interstitial and surface water: implication for stream metabolism and nutrient cycling. Hydrobiologia, 111: 219-228.

Guinasso, N.L., and Schink, D.R. 1975. Quantitative estimates of biological mixing rates in abyssal sediments. J. Geophys. Res. 80: $3032-3043$.

Hansen, K., and Kristensen, E. 1998. The impact of the polychaete Nereis diversicolor and enrichment with macroalgal (Chaetomorpha linum) detritus on benthic metabolism and nutrient dynamics in organic-poor and organic-rich sediment. J. Exp. Mar. Biol. Ecol. 231: 201- 223.

Jones, C.G., Lawton, J.H., and Shachak, M. 1994. Organisms as ecosystem engineers. Oikos, 69: 373-386.

Jonsson, M., and Malmqvist, B. 2003. Mechanisms behind positive diversity effects on ecosystem functioning: testing the facilitation and interference hypotheses. Oecologia, 134: 554-559.

Loreau, M., Naeem, S., Inchausti, P., Bengtsson, J., Grime, J.P., Hector, A., Hooper, D.U., Huston, M.A., Raffaelli, D., Schmid, B., Tilman, D., and Wardle, D.A. 2001. Biodiversity and ecosystem functioning: current knowledge and future challenges. Science (Washington, D.C.), 294: 804-808.

Loreau, M., Naeem, S., and Inchausti, P. (Editors). 2002. Biodiversity and ecosystem functioning. Oxford University Press, Oxford, UK.

Malard, F., and Hervant, F. 1999. Oxygen supply and the adaptations of animals in groundwater. Freshw. Biol. 41: 1-30. 
Marmonier, P., Fontvieille, D., Gibert, J., and Vanek, V. 1995. Distribution of dissolved organic carbon and bacteria at the interface between the Rhône River and its alluvial aquifer. J. North Am. Benthol. Soc. 14: 382-392.

Martinet, F. 1993. Le macrobenthos limnivore, descripteur des flux organiques liés aux sédiments : exemples dans diverses annexes fluviales du Rhône. Ph.D. thesis, University Lyon-I, France.

Mermillod-Blondin, F., Creuzé des Châtelliers, M., Gérino, M., and Gaudet, J.-P. 2000a. Testing the effect of Limnodrilus sp. (Oligochaeta, Tubificidae) on organic matter and nutrient processing in the hyporheic zone: a microcosm method. Arch. Hydrobiol. 149: 467-487.

Mermillod-Blondin, F., Creuzé des Châtelliers, M., Marmonier, P., and Dole-Olivier, M.-J. 2000b. Distribution of solutes, microbes and invertebrates in river sediments along a riffle-pool-riffle sequence. Freshw. Biol. 44: 255-269.

Mermillod-Blondin, F., Gérino, M., Degrange, V., Lensi, R., Chassé, J.-L., Rard, M., and Creuzé des Châtelliers, M. 2001. Testing the functional redundancy of Limnodrilus and Tubifex (Oligochaeta, Tubificidae) in hyporheic sediments: an experimental study in microcosms. Can. J. Fish. Aquat. Sci. 58: 1747-1759.

Mermillod-Blondin, F., Gérino, M., Degrange, V., and Creuzé des Châtelliers, M. 2002. Functional diversity of bioturbation by three detritivorous hyporheic invertebrates: an experimental study in microcosms. J. North Am. Benthol. Soc. 21: 132-149.

Mermillod-Blondin, F., Gaudet, J.-P., Gérino, M., Desrosiers, G., and Creuzé des Châtelliers, M. 2003. Influence of macroinvertebrates on physico-chemical and microbial processes in hyporheic sediments. Hydrol. Processes, 17: 779-794.

Molz, F.J., Widdowson, M.A., and Benefield, L.D. 1986. Simulation of microbial growth dynamics coupled to nutrient and oxygen transport in porous media. Water Resour. Res. 22: 1207-1216.

Morrice, J.A., Dahm, N.D., Valett, H.M., Unnikrishna, P.V., and Campana, M.E. 2000. Terminal electron accepting processes in the alluvial sediments of a headwater stream. J. North Am. Benthol. Soc. 19: 593-608.

Mugnai, C., Gérino, M., Frignani, M., Sauvage, S., and Bellucci, L.G. 2003. Bioturbation experiments in the Venice lagoon. Hydrobiologia, 494: 245-250.

Murphy, E.M., Ginn, T.R., Chilakapati, A., Resch, C.T., Phillips, J.L., Wietsma, T.W., and Spadoni, C.M. 1997. The influence of physical heterogeneity on microbial degradation and distribution in porous media. Water Resour. Res. 33: 1087-1103.

Naeem, S., and Li, S. 1997. Biodiversity enhances ecosystem reliability. Nature (London), 390: 507-509.

Naeem, S., Thompson, L.J., Lawler, S.P., Lawton, J.H., and Woodfin, R.M. 1994. Declining biodiversity can alter the performance of ecosystems. Nature (London), 368: 734-737.

Officer, C.B., and Lynch, D.R. 1982. Interpretation procedures for the determination of sediment parameters from time-dependent flux inputs. Earth Planet. Sci. Lett. 61: 55-62.
Porter, K.G., and Feig, Y.S. 1980. The use of DAPI for identifying and counting aquatic microflora. Limnol. Oceanogr. 25: 943-948.

Raffaelli, D., Emmerson, M., Solan, M., Biles, C., and Paterson, D. 2003. Biodiversity and ecosystem processes in shallow coastal waters: and experimental approach. J. Sea Res. 49: 133-141.

Riisgard, H.U., and Banta, G.T. 1998. Irrigation and deposit feeding by the lugworm Arenicola marina, characteristics and secondary effects on the environment - a review of current knowledge. Vie Milieu, 48: 243-257.

Rodriguez, G.G., Phipps, D., Ishiguro, K., and Ridgway, H.F. 1992. Use of a fluorescent redox probe for direct visualization of actively respiring bacteria. Appl. Environ. Microbiol. 58: 1801-1808.

Sokal, R.R., and Rohlf, J. 1995. Biometry. 3rd ed. W.H. Freeman and Co., New York.

Stief, P., and de Beer, D. 2002. Bioturbation effects of Chironomus riparius on the benthic $\mathrm{N}$-cycle as measured using microsensors and microbiological assays. Aquat. Microb. Ecol. 27: 175-185.

Tachet, H., Richoux, P., Bournaud, M., and Usseglio-Polatera, P. 2000. Invertébrés d'eau douce : systématique, biologie, écologie. CNRS Editions, Paris.

Thullner, M., Mauclaire, L., Schroth, M.H., Kinzelbach, W., and Zeyer, J. 2002. Interaction between water flow and spatial distribution of microbial growth in a two-dimensional flow field in saturated porous media. J. Contam. Hydrol. 58: 169-189.

Torreiter, P., Pitaksintorn-Watanamahart, P., and Danielopol, D.L. 1994. The activity of oligochaetes in relation to their ecological role in slow filtration columns. In Second International Conference on Groundwater Ecology, 27-30 March, Atlanta. USA. Environmental Protectin Agency, AWRA, Herndon, Va. pp. 85-94.

Triska, F.J., Duff, J.H., and Avanzino, R.J. 1993. The role of water exchange between a stream channel and its hyporheic zone in nitrogen cycling at the terrestrial-aquatic interface. Hydrobiologia, 251: $167-184$.

van der Heijden, M.G.A., Klironomos, J.N., Ursic, M., Moutoglis, P., Streitwolf-Engel, R., Boller, T., Wiemken, A., and Sanders, I.R. 1998. Mycorrhizal fungal diversity determines plant biodiversity, ecosystem variability and productivity. Nature (London), 396: 6972.

Wardle, D.A., Bonner, K.I., and Nicholson, K.S. 1997. Biodiversity and plant litter: experimental evidence which does not support the view that enhanced species richness improves ecosystem function. Oikos, 79: 247-258.

Yachi, S., and Loreau, M. 1999. Biodiversity and ecosystem productivity in a fluctuating environment: the insurance hypothesis. Proc. Natl Acad. Sci. USA, 96: 1463-1468.

Yingst, J.Y., and Rhoads, D.C. 1980. The role of bioturbation in the enhancement of microbial turnover rates in marine sediments. In Marine benthic dynamics. Edited by K.R. Tenore and B.C. Coull. University of South Carolina Press, Columbia, S.C. pp. 407-422. 